\title{
Repeated occurrence of surface-sediment remobilization along the landward slope of the Japan Trench by great earthquakes
}

\author{
Ken Ikehara ${ }^{1 *} \mathbb{D}$, Kazuko Usami ${ }^{1,2}$ and Toshiya Kanamatsu ${ }^{3}$
}

\begin{abstract}
Deep-sea turbidites have been utilized to understand the history of past large earthquakes. Surface-sediment remobilization is considered to be a mechanism for the initiation of earthquake-induced turbidity currents, based on the studies on the event deposits formed by recent great earthquakes, such as the 2011 Tohoku-oki earthquake, although submarine slope failure has been considered to be a major contributor. However, it is still unclear that the surface-sediment remobilization has actually occurred in past great earthquakes. We examined a sediment core recovered from the mid-slope terrace (MST) along the Japan Trench to find evidence of past earthquake-induced surface-sediment remobilization. Coupled radiocarbon dates for turbidite and hemipelagic muds in the core show small age differences (less than a few 100 years) and suggest that initiation of turbidity currents caused by the earthquake-induced surfacesediment remobilization has occurred repeatedly during the last 2300 years. On the other hand, two turbidites among the examined 11 turbidites show relatively large age differences ( 5000 years) that indicate the occurrence of large sea-floor disturbances such as submarine slope failures. The sedimentological (i.e., of diatomaceous nature and high sedimentation rates) and tectonic (i.e., continuous subsidence and isolated small basins) settings of the MST sedimentary basins provide favorable conditions for the repeated initiation of turbidity currents and for deposition and preservation of fine-grained turbidites. The MST small basin is a suitable site for examining deep-sea turbidite paleoseismology.
\end{abstract}

Keywords: Surface-sediment remobilization, Turbidity current, Radiocarbon date, Earthquake, Japan Trench

\section{Introduction}

Deep-sea turbidites are a potential tool for submarine paleoseismology (e.g., Adams 1990; Goldfinger et al. 2007, 2012). Earthquakes are a major mechanism for the initiation of turbidity currents, although several alternative mechanisms for the initiation of turbidity currents such as large storm waves, storm surges, hyperpycnal flows (floods), rapid sediment loading, submarine groundwater discharge, volcanic eruptions, and bolide impacts have been proposed (e.g., Nakajima

\footnotetext{
*Correspondence: k-ikehara@aist.go.jp

1 Geological Survey of Japan, National Institute of Advanced Industrial Science and Technology (AIST), Tsukuba Central 7, 1-1-1 Higashi, Tsukuba, Ibaraki 305-8567, Japan

Full list of author information is available at the end of the article
}

2000; Goldfinger et al. 2012; Pickering and Hiscott 2015). It is well-known that earthquake-induced submarine slope failures have generated turbidity currents; e.g., the 1929 Grand Banks earthquake, NW Atlantic (Heezen and Ewing 1952), the 1954 Orleansville earthquake, Algeria (Heezen and Ewing 1955) and the 2006 Pingtung earthquake, Taiwan (Hsu et al. 2008). Thus, submarine slope failure has been considered as a major contributor for generating earthquake-induced turbidity currents. However, the temporal occurrences of bathymetric map-scale submarine slope failures shows longer $\left(10^{3}-10^{5}\right.$ years) recurrence intervals at the edge of the Kumano forearc basin (Kremer et al. 2017; Lackey et al. 2018); temporal occurrences of turbidites in the nearby basins are reported at $10^{2}$ year recurrence intervals (Ikehara 1999, 2001; Okutsu et al. 2019), which are 
similar to the recurrence intervals for interplate earthquakes along the Nankai Trough (Ando 1975). The difference in timing and scale suggests that large mappable landslides are probably not the primary source of the observed turbidites. Surface-sediment remobilization is known as another mechanism for initiation of earthquake-induced turbidites (Moernaut et al. 2017). Some evidence for surface-sediment remobilization for recent earthquakes is discussed using short-lived radionuclides such as ${ }^{137} \mathrm{Cs}$, excess ${ }^{210} \mathrm{~Pb}$ levels, and young, fragile organic matters found in earthquake event deposits (Moernaut et al. 2014, 2017; Oguri et al. 2013; Ikehara et al. 2016; McHugh et al. 2016; Mountjoy et al. 2018), and the depositional gaps in slope sediments (Molenaar et al. 2019). Molenaar et al. (2019) suggested the repeated occurrence of surface-sediment remobilization for a few $\mathrm{cm}$ to $12 \mathrm{~cm}$ from three recent strong earthquakes (2011 Tohoku-oki, 1968 Tokachi-oki and 1896 Sanriku-oki earthquakes). However, evidence for repeated occurrences of surface-sediment remobilizations has been still insufficient.

The 2011 off the Pacific coast of Tohoku (Tohoku-oki) earthquake was an interplate earthquake that occurred along the Japan Trench with an Mw 9.0 (Suzuki et al. 2011). Large ground motions and the subsequent large and destructive tsunami caused severe damage along the Pacific coast of NE Japan. The deep seafloor offshore from Sanriku was disturbed by the earthquake and by the tsunami. Abnormally high turbidity in bottom waters occurred on the Sanriku slope (Noguchi et al. 2012) and on floor of the Japan Trench (Oguri et al. 2013) immediately after the 2011 earthquake. Deep-sea event deposits were reported from the shelf to the trench floor (Arai et al. 2013; Oguri et al. 2013; Ikehara et al. 2014, 2016; Toyofuku et al. 2014; Nomaki et al. 2016; McHugh et al. 2016; Usami et al. 2017). Bao et al. (2018) indicated very small differences in the radiocarbon ages of bulk organic matter in marine sediments between the 2011 event beds and the underlying hemipelagic muds in the core of the Japan Trench. Usami et al. (2018) described repeated occurrences of earthquake-induced turbidites in sediment cores from the mid-slope terrace (MST) on the landward slope of the Japan Trench, and discussed earthquake supercycles along the Japan Trench. The turbidites reported were muddy turbidites with thin basal sand layers and thick upper turbidite mud layers.

In this paper, we wish to determine the age differences between turbidite muds and the underlying hemipelagic muds in a sediment core from the MST, and to examine the repeated occurrence of surface-sediment remobilization due to past earthquakes. We discuss the importance of surface-sediment remobilization for deep-sea turbidite paleoseismology, and suitable sites for paleoseismology investigations using turbidites caused by surface-sediment remobilization.

\section{The mid-slope terrace (MST) and studied materials}

The Pacific plate subducts beneath the Okhotsk plate at a convergence rate of $8.0-8.6 \mathrm{~cm} /$ year to the NW (DeMets et al. 2010). This subduction is associated with tectonic erosion, which induces forearc subsidence (von Huene and Lallemand 1990). Episodic subsidence of the upper slope forms isolated basins (Arai et al. 2014). The MST has been formed by continuous fault activity associated with the backstop interface. The flat MST surface has been maintained by the sediment supply from the slope, which has filled the depressions over the landward-dipping basement by fault activity (von Huene et al. 1980; Tsuru et al. 2002). Each depression occurred in isolation. These features trapped the sediments that were transported by gravity flows from the landward slope with few lateral migrations of sediment transport (von Huene and Culotta 1989; Tsuru et al. 2002; Usami et al. 2018). No submarine canyon connecting between shelf and the MST found off Sanriku slope suggesting that the earthquake is a major mechanism for initiation of the turbidites in the MST deposits. The surface sediments in the MST are generally diatomaceous, reflecting high diatom productivity in the surface water of this region, which has been supported by the high nutrient content of the Oyashio and the upwelling of subsurface water by mixing of the cold Oyashio waters and the warm Kuroshio waters (Saino et al. 1998). Under these conditions, the averaged sedimentation rates for the MST are high $(\sim 100-110 \mathrm{~cm} / \mathrm{ky})$, and many muddy turbidite beds are intercalated in the MST deposits (Usami et al. 2018). Several large $(M>7.6)$ earthquakes have occurred near the study site (Toda 2016). These were the 1994 Sanriku-oki (M 7.6) earthquake, the 1968 Tokachi-oki (M 7.9) earthquake, the 1933 Sanriku-oki (M 8.3) outer rise earthquake, the 1931 (M 7.6) earthquake, the 1987 (M 7.7) earthquake, and the 1896 Sanriku-oki (M 8.2) tsunami earthquake. The 2011 Tohoku-oki (Mw 9.1) earthquake occurred south of the study site.

Core YK14-E01 PC08 (position: 40 08.0264' N, 143 ${ }^{\circ}$ $57.9590^{\prime}$ E, water depth: $4203 \mathrm{~m}$, core length: $487.4 \mathrm{~cm}$ ) was collected from a small basin in the MST off Kuji during the YK14-E01 cruise of R/V Yokosuka (Fig. 1; http://www.jamstec.go.jp/datadoi/doi/10.17596/00016 54.html). The core is composed of diatomaceous muds intercalated with 26 coarse event beds (Fig. 2a). Core photos and radiographs of the core with magnetic susceptibility are shown as Additional file 1: Figure S1. Each event bed is characterized by a sharp base and an upward-fining graded structure that changes from basal coarse layers to muddy upper layers (Fig. 2b, c). 


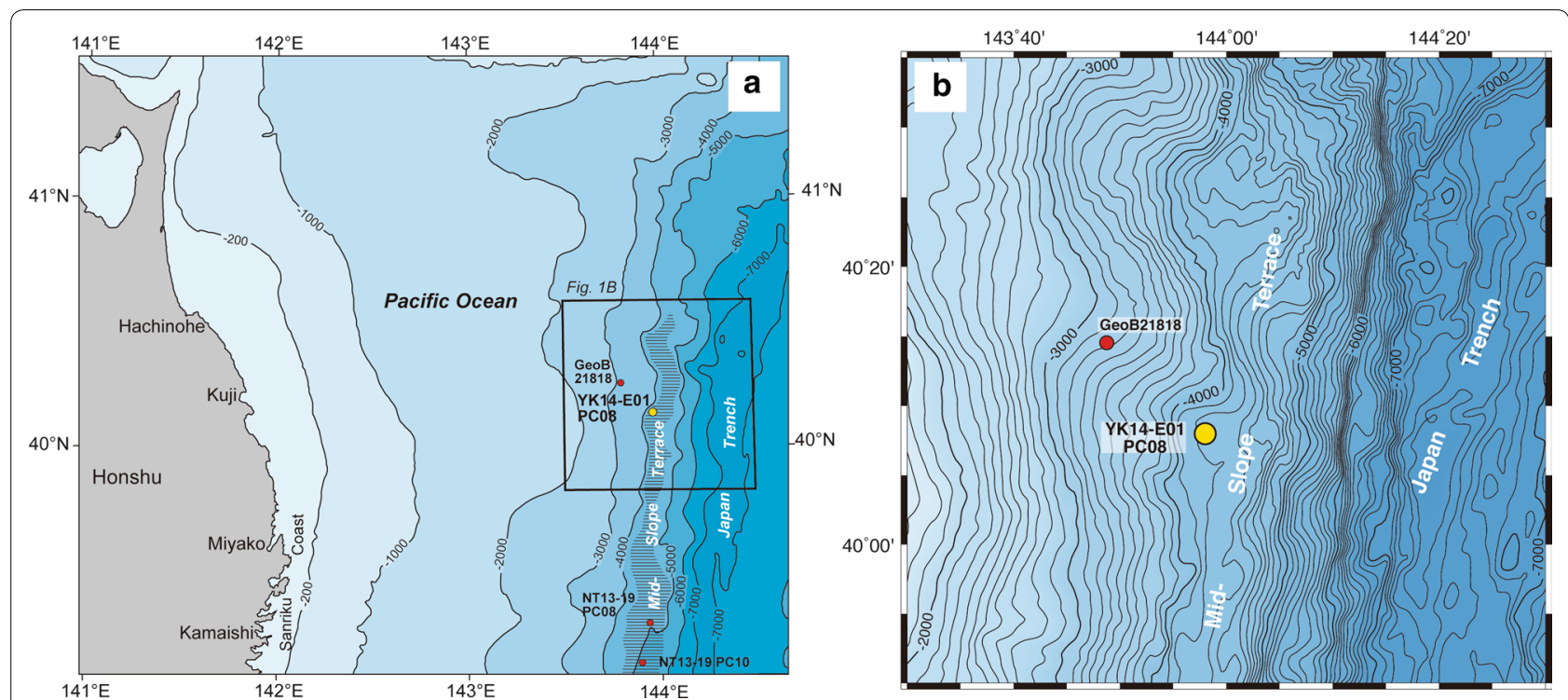

Fig. 1 a Bathymetry and location of the studied coring site (YK14-E01 PC08). Hatched area in a indicates the area of mid-slope terrace. Three coring sites (NT13-19 PC08, PC10 and GeoB21818) are shown. b Detailed bathymetry around the studied coring site
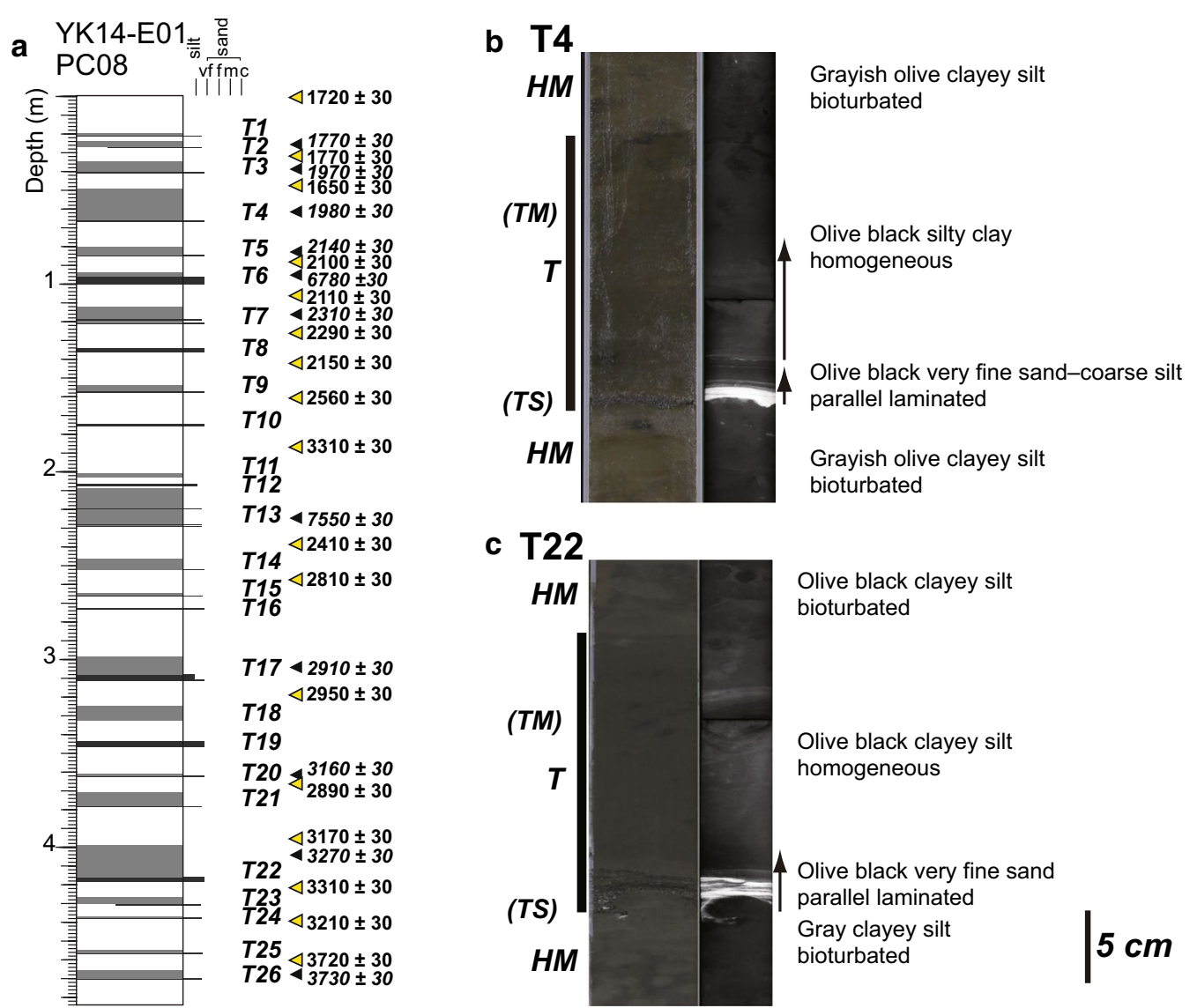

Fig. 2 a Columnar section and results of radiocarbon age determinations, $\mathbf{b}$ core photograph (left), soft-X radiograph (right) and brief sediment description of T4, c core photograph (left), soft-X radiograph (right) and brief sediment description of T22 
Parallel- or cross-laminations are found in some basal coarse layers. Homogeneous muds without bioturbation were found above some coarse event beds. These features suggest that the event beds are considered to be "fine-grained turbidites" (Stow and Shanmugam 1980). Event (turbidite) muds are distinguished from hemipelagic muds by sedimentary structure, bulk density (X-ray transparency) and sediment color (Fig. 2b, c). The turbidite muds are originally homogeneous in structure, although they are occasionally disturbed by post-depositional burrowing, lower transparency in radiographs (suggesting higher bulk densities), and olive black colors. The hemipelagic muds are completely bioturbated, exhibit higher transparency in radiographs (suggesting lower bulk densities), and have gray-grayish olive-olive black colors. Although magnetic susceptibility of the basal coarse layer is high, no significant difference is recognized between turbidite muds and hemipelagic muds (Additional file 1: Figure S1).

A total of 28 radiocarbon age determinations were carried out for 11 turbidite muds and for 17 hemipelagic muds (Fig. 2a and Table 1). Bulk sediment samples of approximately $5-10 \mathrm{~cm}^{3}$ from 1 to $2 \mathrm{~cm}$ intervals were used for measurement. We choose typical and relatively thick hemipelagic and turbidite muds for measurement to avoid mixing of hemipelagic and turbidite muds in the samples. We used bulk organic carbon for the measurements. The bulk samples were washed with acid to remove carbonates prior to the measurements. The radiocarbon dates were measured at the Accelerator Mass Spectrometer radiocarbon facility at Beta Analytics Co. Ltd. We use the conventional radiocarbon ages for discussion.

Table 1 Results of radiocarbon age determinations and age differences between turbidite muds and hemipelagic muds of the examined 11 turbidites

\begin{tabular}{|c|c|c|c|c|c|c|c|}
\hline & Sample depth (cm) & $\begin{array}{l}\text { Conventional }{ }^{14} \mathrm{C} \\
\text { age }\end{array}$ & $\delta^{13} \mathrm{C}$ & Turbidite no. & Age d & & Accession no. \\
\hline 1 & $0-2$ & $1720 \pm 30$ & -20.9 & & & & Beta-485705 \\
\hline 2 & $24-26$ & $1770 \pm 30$ & -20.92 & $\mathrm{~T} 2$ & 0 & $(2-3)$ & Beta-521632 \\
\hline 3 & $30-32$ & $1770 \pm 30$ & -20.21 & & & & Beta-539906 \\
\hline 4 & $38-40$ & $1970 \pm 30$ & -19.07 & $\mathrm{~T} 3$ & 320 & $(4-5)$ & Beta-539907 \\
\hline 5 & $45-47$ & $1650 \pm 30$ & -20.7 & & & & Beta-485704 \\
\hline 6 & $60-62$ & $1980 \pm 30$ & -20.39 & $\mathrm{~T} 4$ & 330 & $(6-5)$ & Beta-536566 \\
\hline 7 & $82-84$ & $2140 \pm 30$ & -21.2 & T5 & 40 & $(7-8)$ & Beta-521633 \\
\hline 8 & $87-89$ & $2100 \pm 30$ & -20.64 & & & & Beta-521634 \\
\hline 9 & $94-96$ & $6780 \pm 30$ & -20.77 & T6 & 4670 & $(9-10)$ & Beta-521635 \\
\hline 10 & $105-107$ & $2110 \pm 30$ & -20.44 & & & & Beta-536567 \\
\hline 11 & $115-117$ & $2310 \pm 30$ & -20.73 & $\mathrm{T7}$ & 20 & $(11-12)$ & Beta-536568 \\
\hline 12 & $125-127$ & $2290 \pm 30$ & -20.76 & & & & Beta-536569 \\
\hline 13 & $141-143$ & $2150 \pm 30$ & -20.8 & & & & Beta-485703 \\
\hline 14 & $160-162$ & $2560 \pm 30$ & -20.75 & & & & Beta- 536570 \\
\hline 15 & $187.2-189.2$ & $3310 \pm 30$ & -20.05 & & & & Beta-539908 \\
\hline 16 & $223.2-225.2$ & $7550 \pm 30$ & -21.98 & $\mathrm{~T} 13$ & 5140 & $(16-17)$ & Beta-536571 \\
\hline 17 & $237.2-239.2$ & $2410 \pm 30$ & -20.6 & & & & Beta-485702 \\
\hline 18 & $254.7-256.7$ & $2810 \pm 30$ & -19.34 & & & & Beta-539909 \\
\hline 19 & $303.1-305.1$ & $2910 \pm 30$ & -20.75 & $\mathrm{~T} 17$ & -40 & $(19-20)$ & Beta-536572 \\
\hline 20 & $321.1-323.1$ & $2950 \pm 30$ & -20.39 & & & & Beta-536573 \\
\hline 21 & $361.1-362.1$ & $3160 \pm 30$ & -20.8 & $\mathrm{~T} 20$ & 270 & $(21-22)$ & Beta-521636 \\
\hline 22 & $366.1-368.1$ & $2890 \pm 30$ & -20.8 & & & & Beta-485701 \\
\hline 23 & $394.9-396.9$ & $3170 \pm 30$ & -20.78 & & & & Beta-536574 \\
\hline 24 & $402.9-404.9$ & $3270 \pm 30$ & -20.73 & T22 & -40 & $(24-25)$ & Beta-536575 \\
\hline 25 & $419.9-421.9$ & $3310 \pm 30$ & -19.77 & & & & Beta-539910 \\
\hline 26 & $437.9-439.9$ & $3210 \pm 30$ & -20.9 & & & & Beta-485700 \\
\hline 27 & $459.9-461.9$ & $3720 \pm 30$ & -20.71 & & & & Beta-536576 \\
\hline 28 & $466.9-468.9$ & $3730 \pm 30$ & -20.85 & T26 & 10 & $(28-27)$ & Beta-536577 \\
\hline
\end{tabular}




\section{Results and discussion}

\section{Sediment depositional ages and turbidite occurrences}

The radiocarbon dates of the hemipelagic muds generally become older with increasing the sub-bottom depths (Figs. 2a and 3 and Table 1). Although the radiocarbon dates for some horizons are slightly older than those of the underlying horizons, the relationship between the radiocarbon ages and the turbidite-free depths shows a linear relationship with a calculated averaged sedimentation rate of $200 \mathrm{~cm} / \mathrm{ky}$. The radiocarbon date of the core-top hemipelagic mud $(1720 \pm 30$ years BP) indicates that the radiocarbon date of the bulk organic matter in the hemipelagic mud has a 1700 years offset from the true age. This offset is similar to those seen in the Japan Trench ( 1600 years; Ikehara et al. 2016; Bao et al. 2018). The radiocarbon date of the hemipelagic mud near the core bottom is $3720 \pm 30$ years BP. Considering that the age offset is 1600 years and assuming the same sedimentation rate near the core bottom, the inferred core-bottom age is $\sim 2300$ years BP. Thus, our core records the late Holocene depositional history at the MST off Kuji.

A total of 26 turbidite beds (T1-T26) were recognized in core YK14-E01 PC01 (Fig. 2a). Usami et al. (2018) established a precise age model for two cores (namely, cores NT13-19 PC08 (39 $\left.16.4448^{\prime} \mathrm{N}, 143^{\circ} 56.6842^{\prime} \mathrm{E}\right)$ and $\mathrm{PC} 10\left(39^{\circ} 07.2353^{\prime} \mathrm{N}, 143^{\circ} 54.1586^{\prime} \mathrm{E}\right)$ ) that were recovered from the MST off Kamaishi, based on tephrochronology, paleomagnetic secular variation, and shortlived radioisotope activity $\left({ }^{137} \mathrm{Cs}\right.$ and excess $\left.{ }^{210} \mathrm{~Pb}\right)$, and

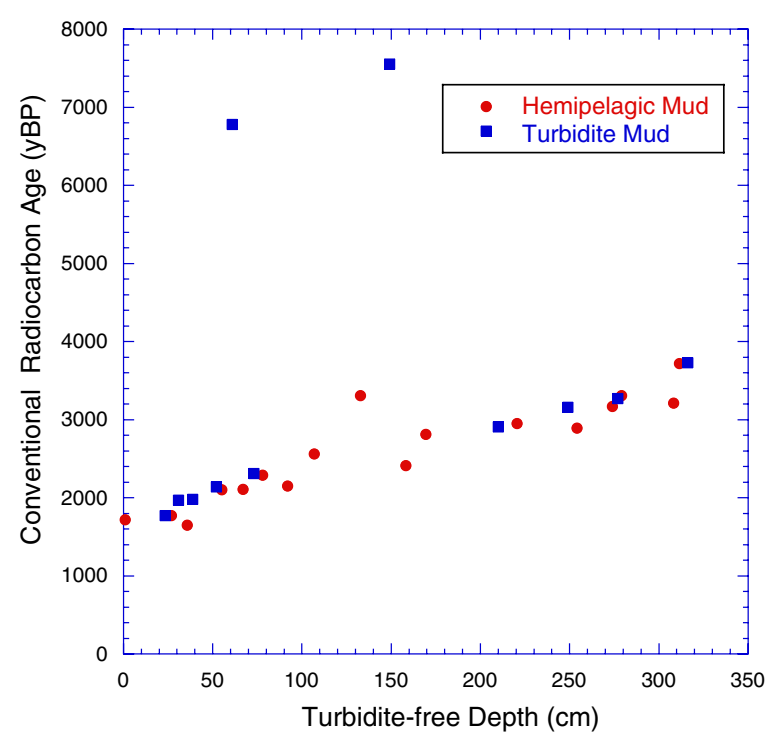

Fig. 3 Relationships between the radiocarbon ages of hemipelagic muds and turbidite-free sub-bottom depth. Ages of turbidite mud are plotted at the depths of boundaries between the overlying and underlying hemipelagic muds also recognized $\sim 12$ turbidites from the last $4 \mathrm{ky}$. Our coring site is located north of their sites (Fig. 1). The turbidite frequencies are thought to be higher in our core than those reported by Usami et al. (2018). Although there is a possibility that some turbidites in our core are correlative to those of Usami et al. (2018), our present age model based on radiocarbon dates of bulk organic carbon, contains much uncertainty for the precise correlations because of the age offset between the radiocarbon dates of the bulk organic carbon and those of the planktonic foraminifera or the actual depositional dates (Ikehara 2000; Ikehara et al. 2016; Bao et al. 2018). Thus, it is necessary to conduct further chronological work such as paleomagnetic secular variation (Kanamatsu et al. 2017), for the precise correlations and depositional age determinations of each turbidite.

\section{Age differences between paired turbidite muds and hemipelagic muds and evidence of surface-sediment remobilization}

The age differences between the turbidite muds and the underlying or overlaying hemipelagic muds are summarized in Table 1 . They range from -40 years (T17 and T20) to 5140 years (T13). Except for T6 and T13, the differences are small and are less than a few 100 years ( -40 to 330 years). The small age differences between the turbidite muds and the hemipelagic muds in the 9 turbidites among the 11 examined turbidites (Table 1) are likely evidence of surface-sediment remobilization. Bao et al. (2018) indicated small age differences between the 2011 Tohoku-oki earthquake-induced turbidites and the underlying hemipelagic muds on the Japan Trench floor. The 2011 turbidites in the nearby basin contained the short-lived radionuclides $\left({ }^{137} \mathrm{Cs}\right.$ and excess $\left.{ }^{210} \mathrm{~Pb}\right)$ (Oguri et al. 2013; Ikehara et al. 2016), and are considered to be the results of surface-sediment remobilization. Thus, surface-sediment remobilization has occurred repeatedly due to the past great earthquakes. On the other hand, two turbidites (e.g., T6 and T13) show relatively large age differences of 4690 and 5140 years, respectively. This suggests that much larger disturbances of the sea floor, such as small submarine slope failures or older sediment mobilization might have been caused by some great earthquakes. It is interesting that the thicknesses of the two turbidites are quite different. Although the T13 turbidite is the thickest turbidite $(20.7 \mathrm{~cm}$ thick) in this core, the T6 turbidite has a normal thickness $(6 \mathrm{~cm}$ thick). We do not understand what differences in the magnitudes and types of earthquakes and of the ground shaking mode have caused such differences on the initiation of turbidity currents. Detailed correlation of the turbidites in the sediment cores recovered from the MST (McHugh 
et al. 2016; Usami et al. 2018) is important to clarify the origin.

The age differences indicate that sediments less than a few 100 years old (on average) were remobilized and formed turbidites. The averaged sedimentation rates of turbidite-free hemipelagic muds in core YK14-E01 PC08 are calculated to be $\sim 155 \mathrm{~cm} / \mathrm{ky}$, and those in cores NT13-19 PC08 and PC10 are calculated to be $72-80 \mathrm{~cm} /$ ky. These age differences correspond to only a few to $46 \mathrm{~cm}$ in the sediment thicknesses in the MST sediments. The sedimentation rates for the landward slope of the MST have not been clearly determined. Although Molenaar et al. (2019) reported the sedimentation rate of the surficial (15 cm thick) sediments in core GeoB21818 $\left(40^{\circ} 14.790^{\prime} \mathrm{N}, 143^{\circ} 48.918^{\prime} \mathrm{E}\right)$ on the slope at $3139 \mathrm{~m}$ water depth near our coring site (Fig. 1) to be $1.0-3.5 \mathrm{~mm} /$ year $(100-350 \mathrm{~cm} / \mathrm{ky})$ from the excess ${ }^{210} \mathrm{~Pb}$ activity profile, the seismic profiles of the landward slope of the Japan Trench suggest thin surface-sediment cover except for the MST (Tsuru et al. 2002; Arai et al. 2014). Therefore, much thinner surface sediments than the abovementioned estimations were most likely remobilized and flowed downward as turbidity currents and formed the turbidites in the small basins of the MST. This idea is supported by the results of Molenaar et al. (2019), who estimated the remobilization depths on the slope to be $>2-12 \mathrm{~cm}$.

The mechanism for surface-sediment remobilization is still unclear. Oguri et al. (2016) observed resuspension of unconsolidated surface sediments due to an aftershock (M 7.3) of the 2011 Tohoku-oki earthquake on the upper slope (998 m in water depth) off Sanriku. Thus, strong ground shaking by a great earthquake might have the potential to resuspend the surface sediments. Abnormally high turbidity of the bottom water on the Sanriku slope immediately (around 1 month) after the 2011 Tohoku-oki earthquake (Noguchi et al. 2012) also suggests a high level of surface-sediment resuspension. The similar abnormally high turbidity of bottom waters was observed on the landward slope of the Nankai Trough off Kumano due to the 2004 Kii-Hanto earthquake (Ashi et al. 2014). Based on the sediment volume of the earthquake-induced event deposit (an acoustically transparent layer in sub-bottom profiles) in a slope basin and a possible sediment source area on the surrounding slope, Ashi et al. (2014) estimated that surface sediments less than a few $\mathrm{cm}$ thick on the slope around the basin were remobilized by the earthquake ground shaking and formed an acoustically transparent deposit in the basin. Molenaar et al. (2019) inferred centimeter-scale surface-sediment remobilization on the slope off of northern Sanriku based on the excess ${ }^{210} \mathrm{~Pb}$ activity in the surface sediments. Diatomaceous sediments have lower cohesion than clayey sediments. The diatomaceous nature of the surface sediments on the Sanriku slope might influence to easy resuspension of the surface sediments, and contribute to generate turbidity currents, which transported sediments downward.

\section{Suitable depositional settings for paleoseismology using turbidites caused by surface-sediment remobilization}

From a paleoseismological point of view, it is better that the earthquake-induced turbidites are formed in the geological record by each great earthquake. Although large (bathymetry-scale) submarine slope failures are considered to be a major contributors to earthquakeinduced turbidites, based on the submarine cable breaks (e.g., Heezen and Ewing 1952, 1955; Hsu et al. 2008), the reported recurrence intervals of large submarine slope failures along the Nankai Trough (Kremer et al. 2017; Lackey et al. 2018) are longer than those of the turbidites (Ikehara 1999, 2001; Okutsu et al. 2019). Thus, the surface-sediment remobilization is another possible mechanism for forming earthquake-induced turbidites. In general, fine-grained sediment is distributed widely in deep-sea environments. Fine-grained surface sediments may resuspend easily and broadly when compared with coarse-grained sediments due to their smaller grain weights. The presence of unconsolidated surface sediments on the slope when a great earthquake occurs is essential for the repeated occurrence of surface-sediment remobilization. Unconsolidated sediments should deposit and recharge before the next great earthquake. Thus, the sedimentation rates on the slope are another important factor (Ikehara and Usami, 2018). High sedimentation along the MST likely acts as a positive environmental factor for the repeated generation of turbidity currents caused by surface-sediment remobilization. High sedimentation rates also provide high preservation potential for turbidites through effective burial, thus avoiding destruction of turbidite by benthos activities.

For paleoseismological purposes, site selection for sediment coring is an important (e.g., Goldfinger et al. 2012, 2017). Here, we discuss suitable conditions for the repeated deposition of fine-grained turbidites. For deposition of fine-grained turbidites, ponding of turbid water masses may be important (e.g., Van Andel and Komar 1969; Moernaut et al. 2014; Patacci et al. 2015). Small basins or depressions (minibasins) on the slope likely acts as traps for turbidity currents coming from the landward slope. Terminal basins most likely trap the turbidity currents and form mud ponds. Formation of a 2.5 m thick mud pond (extremely turbid bottom water) by the 2004 Kii-Hanto earthquake was reported for a terminal slope basin off Kumano (Ashi et al. 2014). Continuous basin subsidence by tectonic activity associated with plate 
subduction is favorable for maintaining the accommodation space in the basin. The small MST basins have been formed by continuous fault activity related to the backstop interface (von Huene et al. 1980; Tsuru et al. 2002). The tectonic movements cause the small MST basins to be suitable places for turbidite paleoseismology investigations (Fig. 4).

Connectivity between small basins is another important factor for turbidite paleoseismology. Easy connections between basins allow turbidity currents to flow long distances through canyons and channels. For example, axial turbidity currents along the Nankai Trough have flowed $600 \mathrm{~km}$ from Suruga Bay to off Shikoku (Taira and Niitsuma 1986; Pickering et al. 1993). Patton et al. (2013) also discussed this problem by comparing Sumatra and Cascadia margin examples. This means that a turbidity current caused by an earthquake in a neighboring segment is able to flow into the basins of the other segments, and then, in the turbidites of a distal basin, the earthquakes that occurred in multiple segments are recorded. Under these conditions, it is difficult to understand where the rupture area of earthquake was. This is unsuitable for precise analysis of past earthquakes. Series of isolated small basins such as those on the floor of the Japan Trench axis (Ikehara et al. 2018; Kioka et al. 2019a, Kioka et al. 2019b), are considered to be better settings for turbidite paleoseismology than well-connected basins because the turbidite record in a basin represents a local record of great earthquakes. This was also discussed by Goldfinger et al. (2012) at the Cascadia margin. Small basins along the MST are isolated from each other and lateral transport among the basins by turbidity currents is thought to be small (von Huene and Culotta 1989; Tsuru et al. 2002; Usami et al. 2018).

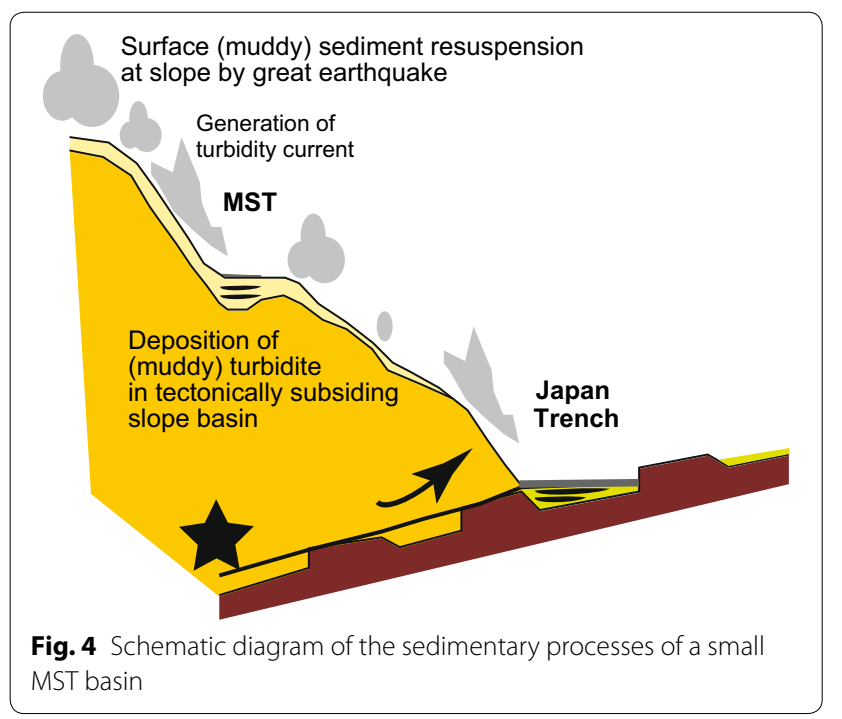

\section{Conclusions}

We examined a sediment core recovered from the MST along the Japan Trench to find evidence of earthquakeinduced surface-sediment remobilization in the past. The coupled radiocarbon dates of the turbidite muds and hemipelagic muds in the core show small age differences and suggest that the initiation of turbidity currents caused by earthquake-induced surface-sediment remobilization is a common feature and has occurred repeatedly during the last 2300 years. On the other hand, two turbidites among the 11 examined turbidites show relatively large age differences ( $~ 5000$ years), indicating the occurrence of larger sea-floor disturbances such as submarine slope failures or older sediment mobilization. The sedimentological (i.e., of diatomaceous nature and high sedimentation rates) and tectonic (i.e., continuous subsidence and isolated small basin) settings of the MST basins and the nearby slopes provide favorable conditions for the repeated initiation of turbidity currents by surface-sediment remobilization due to great earthquakes and fine-grained turbidite deposition. The small MST basins are thought to be suitable sites for deep-sea turbidite paleoseismology.

\section{Supplementary information}

Supplementary information accompanies this paper at https://doi. org/10.1186/s40623-020-01241-y.

Additional file 1: Figure S1. Core photograph, radiograph and magnetic susceptibility profile of core YK14-E01 PC08 Section 1 was no sample. Radiographs were taken for slab samples (20 cm long and $1 \mathrm{~cm}$ thick). Magnetic susceptibility was measured using continuous paleomagnetic plastic cube samples (7 cc)

\section{Abbreviation}

MST: Mid-slope terrace.

\section{Acknowledgements}

We express our thanks to the captain, officers, crews and marine technicians of the RN Yokosuka YK14-E01 cruise. Thanks are extended to Prof. Chris Goldfinger and an anonymous reviewer for their constructive comments.

\section{Authors' contributions}

$\mathrm{KI}$ and $\mathrm{KU}$ conducted the sedimentological analyses and interpretations, and constructed the age model. TK led the cruise and sediment sampling, and conducted the magnetic susceptibility measurement. All authors read and approved the final manuscript.

\section{Funding}

This work was supported by KAKENHI "Japan Trench Deep-sea Research Project for Assessing Shallow Seismic Slips and Their History, Ministry of Education, Culture, Sports, Science and Technology (No. 26000002)" and by the MEXT research projects "Geophysical and Geological Studies of Earthquakes and Tsunamis for off-Tohoku District, Japan" and "Research Project for Compound Disaster Mitigation on the Great Earthquakes and Tsunamis around the Nankai Trough Region".

Availability of data and materials

Please contact the corresponding author for data request. 


\section{Competing interests}

The authors declare that they have no competing interests.

\section{Author details}

${ }^{1}$ Geological Survey of Japan, National Institute of Advanced Industrial Science and Technology (AIST), Tsukuba Central 7, 1-1-1 Higashi, Tsukuba, Ibaraki 305-8567, Japan. ${ }^{2}$ Japan NUS Co. Ltd., Energy Consulting Department, Safety and Environmental Analysis Unit, Nishi-Shinjuku Prime Square 5F, 7-5-25 Nishi-Shinjuku, Shinjuku-ku, Tokyo 160-0023, Japan. ${ }^{3}$ Research Institute of Marine Geodynamics, Japan Agency for Marine-Earth Science and Technology (JAMSTEC), 2-15 Natsushima-cho, Yokosuka, Kanagawa 237-0046, Japan.

Received: 7 May 2020 Accepted: 28 July 2020

Published online: 08 August 2020

\section{References}

Adams J (1990) Paleoseismicity of the Cascadia subduction zone: evidence from turbidites off the Oregon-Washington margin. Tectonics 9:569-583

Ando M (1975) Source mechanisms and tectonic significance of historical earthquakes along the Nankai Trough, Japan. Tectonophys 27:119-140

Arai K, Naruse H, Miura R, Kawamura K, Hino R, Ito Y, Inazu D, Yokokawa M, Izumi N, Murayama M, Kasaya T (2013) Tsunami-generated turbidity current of the 2011 Tohoku-Oki earthquake. Geology 41:1195-1198. https:// doi.org/10.1130/G34777.1

Arai K, Inoue T, Ikehara K, Sasaki T (2014) Episodic subsidence and active deformation of the forearc slope along the Japan Trench near the epicenter of the 2011 Tohoku Earthquake. Earth Planet Sci Lett 408:9-15. https://doi. org/10.1016/j.epsl.2014.09.048

Ashi J, Sawada R, Omura A, Ikehara K (2014) Accumulation of an earthquake-induced extremely turbid layer in a terminal basin of the Nankai accretional prism. Earth Planets Space 66:1-9. https://doi. org/10.1186/1880-5981-66-51

Bao R, Strasser M, McNichol AP, Haghipour N, McIntyre C, Wefer G, Eglinton TI (2018) Tectonically-triggered sediment and carbon export to the Hadal zone. Nat Commun 9:121. https://doi.org/10.1038/s41467-017-02504-1

DeMets C, Gordon RG, Argus DF (2010) Geologically current plate motions. Geophys J Int 181:1-80. https://doi.org/10.1111/j.1365-246X.2009.04491.x

Goldfinger C, Morey AE, Hans Nelson C, Gutierrez-Pastor J, Johnson JE, Karabanov E, Chaytor J, Eriksson A, Party SS (2007) Rupture lengths and temporal history of significant earthquakes on the offshore and north coast segments of the Northern San Andreas Fault based on turbidite stratigraphy. Earth Planet Sci Lett 254:9-27. https://doi.org/10.1016/j. epsl.2006.11.017

Goldfinger C, Hans Nelson C, Morey AE, Johson JE, Patton JR, Karabanov E, Gutierrez-Pator J, Eriksson AT, Gracia E, Dunhill G, Enkin RJ, Dallimore A, Vallier T (2012) Turbidite event history -Methods and implications for Holocene paleoseismicity of the Cascadia subduction zone. USGS Professional Paper, 1661-F, 184 pp., US Geological Survey, https://doi. org/10.3133/pp1661f

Goldfinger C, Galer S, Beeson J, Hamilton T, Black B, Romsos C, Patton J, Hans Nelson C, Haumann R, Morey A (2017) The importance of site selection, sediment supply, and hydrodynamics: a case study of submarine paleoseismology on the northern Cascadia margin, Washington USA. Mar Geol 384:4-46. https://doi.org/10.1016/j.margeo.2016.06.008

Heezen BC, Ewing M (1952) Turbidity currents and submarine slumps, and the 1929 Grand Banks Earthquake. Am J Sci 250:849-873. https://doi. org/10.2475/ajs.250.12.849

Heezen BC, Ewing M (1955) Orleansville Earthquake and turbidity currents. Bull Am Ass Petrol Geol 39:2505-2514. https://doi.org/10.1306/5CEAE 2E6-16BB-11D7-8645000102C1865D

Hsu S-K, Kuo J, Lo C-L, Tsai C-H, Doo W-B, Ku C-Y, Sibuet J-C (2008) Turbidity currents, submarine landslides and the 2006 Pingtung Earthquake off SW Taiwan. Terr Atmos Ocean Sci 19:767-772. https://doi.org/10.3319/ TAO.2008.19.6.767(PT)

Ikehara K (1999) Recurrence interval of deep-sea turbidites and its importance for paleoseismicity analysis: an example from a piston core analysis from Kumano Trough, southwest Japan forearc. J Sed Soc Japan 49:13-21. https://doi.org/10.4096/jssj1995.49.13 (in Japanese with Eng abstract)
Ikehara K (2000) Comparison of radiocarbon ages of planktonic foraminifera and bulk organic carbon in marine sediments. Bull Geol Surv Japan 51:299-307 (in Japanese with Eng abstract)

Ikehara K (2001) Recurrence interval of large earthquakes along the eastern Nankai Trough inferred from deep-sea turbidites. J Geogr (Chigaku Zasshi) 110:471-478. https://doi.org/10.5026/jgeography.110.4_471 (in Japanese with Eng abstract)

Ikehara K, Usami K (2018) Submarine earthquake- and tsunami-induced event deposits: disturbance of sea floor by huge earthquakes and their related tsunamis, and use of disturbance records in marine sediments for history of past huge earthquakes and tsunamis. Synthesiology 11:13-23. https:// doi.org/10.5571/syntheng.11.1_13

Ikehara K, Irino T, Usami K, Jenkins R, Omura A, Ashi J (2014) Possible submarine tsunami deposits on the outer shelf of Sendai Bay, Japan resulting from the 2011 earthquake and tsunami off the Pacific coast of Tohoku. Mar Geol 358:120-127. https://doi.org/10.1016/j.margeo.2014.11.004

Ikehara K, Kanamatsu T, Nagahashi Y, Strasser M, Fink H, Usami K, Irino T, Wefer G (2016) Documenting large earthquakes similar to the 2011 Tohoku-oki earthquake from sediments deposited in the Japan Trench over the past 1500 years. Earth Planet Sci Lett 445:48-56. https://doi.org/10.1016/j. epsl.2016.04.009

Ikehara K, Usami K, Kanamatsu T, Arai K, Yamaguchi A, Fukuchi R (2018) Spatial variability in sediment lithology and sedimentary processes along the Japan Trench: use of deep-sea turbidite records to reconstruct past large earthquakes. Tsunami 456:75-89. https://doi.org/10.1144/SP456.9

Kanamatsu T, Usami K, McHugh CM, Ikehara K (2017) High-resolution chronology of sediment below CCD based on Holocene paleomagnetic secular variations in the Tohoku-oki earthquake rupture zone. Geochem Geophys Geosys 18:2990-3002. https://doi.org/10.1002/2017GC006878

Kioka A, Schwestermann T, Moernaut J, Ikehara K, Kanamatsu T, McHugh CM, dos Santos Ferreira C, Wiermer G, Haghipour N, Kopf AJ, Eglinton TI, Strasser M (2019a) Megathrust earthquake drives drastic organic carbon supply to the hadal trench. Sci Rep 9:1553. https://doi.org/10.1038/s4159 8-019-38834-x

Kioka A, Schwestermann T, Moernaut J, Ikehara K, Kanamatsu T, Eglinton TI, Strasser M (2019b) Event stratigraphy in a hadal oceanic trench: the Japan Trench as sedimentary archive recording recurrent giant subduction zone earthquakes and their role in organic carbon export to the deep sea. Front Earth Sci 7:319. https://doi.org/10.3389/feart.2019.00319

Kremer K, Usman MO, Satoguchi Y, Nagahashi Y, Vadakkepuliyambatta S, Panieri G, Strasser M (2017) Possible climate preconditioning on submarine landslides along a convergent margin, Nankai Trough (NE Pacific). Prog Earth Planet Sci 4:20. https://doi.org/10.1186/s40645-017-0134-9

Lackey J, Moore G, Strasser M (2018) Three-demensional mapping and kinematic characterization of mass transport deposits along the outer Kumano Basin and Nankai accretionary wedge, southwest Japan. Prog Earth Planet Sci 5:65. https://doi.org/10.1186/s40645-018-0223-4

McHugh CM, Kanamatsu T, Seeber L, Bopp R, Cormier M-H, Usami K (2016) Remobilization of surficial slope sediment triggered by the A.D. 2011 Mw9 Tohoku-Oki earthquake and tsunami along the Japan Trench. Geology 44:391-394. https://doi.org/10.1130/G37650.1

Moernaut J, Van Daele M, Heirman K, Fontjin K, Strasser M, Pino M, Urrutia R, De Batist M (2014) Lacustrine turbidites as a tool for quantitative earthquake reconstruction: new evidence for a variable rupture model in South Central Chike. J Geophys Res Solid Earth 119:1607-1633. https:// doi.org/10.1002/2013JB010738

Moernaut J, Van Daele M, Strasser M, Clare MA, Heirman K, Viel M, Cardenas J, Kilian R, de Guevara BL, Pino M, Urrutia R, De Batist M (2017) Lacustrine turbidites produced by surficial slope sediment remobilization: a mechanism for continuous and sensitive turbidite paleoseismic records. Mar Geol 384:159-176. https://doi.org/10.1016/j.margeo.2015.10.009

Molenaar A, Moernaut J, Wiemer G, Dubois N, Strasser M (2019) Earthquake impact on active margins: tracing surficial remobilization and seismic strengthening in a slope sedimentary sequence. Geophs Res Lett. https:// doi.org/10.1029/2019gl082350

Mountjoy JJ, Howath JD, Orpin AR, Barnes PM, Bowden DA, Rowden AA, Schimel ACG, Holden C, Horgan HJ, Nodder SD, Patton JR, Lamarche G, Gerstenberger M, Micallef A, Pallentin A, Kane T (2018) Earthquakes drive large-scale submarine canyon development and sediment supply to deep-ocean basins. Sci Adv 4:eaar3748. https://doi.org/10.1126/sciad v.aar3748 
Nakajima T (2000) Initiation processes of turbidity currents: implications for assessment of recurrence intervals of offshore earthquakes using turbidites. Bull Geol Surv Japan 51:79-87 (in Japanese with Eng abstract)

Noguchi T, Tanikawa W, Hirose T, Lin W, Kawagucci S, Yoshida-Takashima Y, Honda MC, Takai K, Kitazato H, Okamura K (2012) Dynamic process of turbidity generation triggered by the 2011 Tohoku-Oki earthquake. Geochem Geophys Geosys 13:Q11003. https://doi.org/10.1029/2012G C004360

Nomaki H, Arai K, Suga H, Toyofuku T, Wakita M, Nunoura T, Oguri K, Kasaya T, Watanabe S (2016) Sedimentary organic matter contents and porewater chemistry at upper bathyal depths influenced by the 2011 off the Pacific coast of Tohoku Earthquake and tsunami. J Oceanogr 72:99-111. https:// doi.org/10.1007/s10872-015-0315-3

Oguri K, Kawamura K, Sakaguchi A, Toyofuku T, Kasaya T, Murayama M, Fujikura K, Glud RN, Kitazato H (2013) Hadal disturbance in the Japan Trench induced by the 2011 Tohoku-Oki Earthquake. Sci Rep 3:1915. https://doi. org/10.1038/srep01915

Oguri K, Furushima Y, Toyofuku T, Kasaya T, Wakita M, Watanabe S, Fujikura K, Kitazato H (2016) Long-term monitoring of bottom environments of the continental slope off Otsuchi Bay, northeastern Japan. J Oceanogr 72:151-166. https://doi.org/10.1007/s10872-015-0330-4

Okutsu N, Ashi J, Yamaguchi A, Irino T, Ikehara K, Kanamatsu T, Suganuma Y, Murayama M (2019) Evidence for surface sediment remobilization by earthquakes in the Nankai forearc region from sedimentary records, Submarine Mass Movements and Their Consequences: assessing Geohazards, Environmental Implications. Geol Soc London Spec Publ No. 477:37-45. https://doi.org/10.1144/SP477.22

Patacci M, Haughton PDW, McCaffrey WD (2015) Flow behavior of ponded turbidity currents. J Sed Res 85:885-902. https://doi.org/10.2110/jsr.2015.59

Patton JR, Goldfinger C, Morey A, Rosmos C, Black B, Djadjadihardia YS, Udrekh (2013) Seismoturbidite record as preserved at core sites at the Cascadia and Sumatra-Andaman subduction zones. Nat Hazards Earth Sci Sys 13:833-867. https://doi.org/10.5194/nhess-13-833-2013

Pickering KT, Hiscott RN (2015) Deep marine systems: processes, deposits, environments, tectonics and sedimentation. AGU and Wiley, 657p

Pickering KT, Underwood MB, Taira A (1993) Open-ocean to trench turbiditycurrent flow in the Nankai Trough: flow collapse and flow reflection. Geology 20:1099-1102. https://doi.org/10.1130/0091-7613(1992)020\%3c109 9:OOTTTC\%3e2.3.CO;2

Saino T, Shang S, Mino Y, Suzuki K, Nomura H, Saito S, Miyake H, Masuzawa T, Harada K (1998) Short term variability of particle fluxes and its relation to variability in sea surface temperature and Chlorophyll a field detected by ocean color and temperature scanner (OCTS) off Sanriku, Northwestern North Pacific in the spring of 1997. J Oceanogr 54:583-592. https://doi. org/10.1007/BF02742460

Stow DAV, Shanmugam G (1980) Sequence of structures in fine-grained turbidites: comparison of recent deep-sea and ancient flysch sediments. Sed Geol 25:23-42. https://doi.org/10.1016/0037-0738(80)90052-4
Suzuki W, Aoi S, Sekiguchi H, Kunugi T (2011) Rupture process of the 2011 Tohoku-Oki mega-thrust earthquake (M9.0) inverted from strong-motion data. Geophys Res Lett 38:16. https://doi.org/10.1029/2011

Taira A, Niitsuma N (1986) Turbidite sedimentation in the Nankai Trough as interpreted from magnetic fabric, grain size, and detrital modal analysis. In: Karig DE, Coulbourn WT et al. Init. Rep. DSDP 87: 611-632, https://doi. org/10.2973/dsdp.proc.87.112.1986

Toda S (2016) Crustal earthquakes. In: The Geology of Japan, Geol. Soc., London, 371-408, https://doi.org/10.1144/goj.14

Toyofuku T, Duros P, Fontainer C, Mamo B, Bichon S, Buscail R, Chabaud G, Deflandre B, Gouber S, Gremare A, Mennifi C, Fujii M, Kawamura K, Koho KA, Noda A, Namegaya Y, Oguri K, Radakovitch O, Murayama M, Jan de Nooijer L, Kurasawa A, Ohkawa N, Okutani T, Sakaguchi A, Jorissen F, Reichart G-J, Kitazato H (2014) Unexpected biotic resilience on the Japanese seafloor caused by the 2011 Tohoku-Oki tsunami. Sci Rep 4:7517. https://doi.org/10.1038/srep07517

Tsuru T, Park J-O, Miura S, Kodaira S, Kido Y, Hayashi T (2002) Along-arc structural variation of the plate boundary at the Japan Trench margin: implication of interplate coupling. J Geophys Res 107(B12):2357. https:// doi.org/10.1029/2001JB001664

Usami K, Ikehara K, Jenkins RG, Ashi J (2017) Benthic foraminiferal evidence of deep-sea sediment transport by the 2011 Tohoku-oki earthquake and tsunami. Mar Geol 384:214-224. https://doi.org/10.1016/j.marge 0.2016 .04 .001

Usami K, Ikehara K, Kanamatsu T, McHugh CM (2018) Supercycle in great earthquake recurrence along the Japan Trench over the last 4000 years. Geosci Lett 5:11. https://doi.org/10.1186/s40562-018-0110-2

van Andel TH, Komar PD (1969) Ponded sediments of the Mid-Atlantic Ridge between $22^{\circ}$ and $23^{\circ}$ North latitude. Geol Soc Am Bull 80:11631190. https://doi.org/10.1130/0016-7606(1969)80\%5b1163:PSOTM $\mathrm{R} \% 5 \mathrm{~d} 2.0 . \mathrm{CO} ; 2$

von Huene R, Culotta R (1989) Tectonic erosion at the front of the Japan Trench convergent margin. Tectonophys 160:75-90. https://doi. org/10.1016/0040-1951(89)90385-5

von Huene R, Lallemand S (1990) Tectonic erosion along the Japan and Peru convergent margins. Geol Soc Am Bull 102:704-720. https://doi. org/10.1130/0016-7606(1990)102\%3c0704:TEATJA\%3e2.3.CO;2

von Huene R, Langseth M, Nasu N, Okada H (1980) Summary. Japan Trench transect. Init Rep DSDP 56(57):473-488. https://doi.org/10.2973/dsdp. proc.5657.111.1980

\section{Publisher's Note}

Springer Nature remains neutral with regard to jurisdictional claims in published maps and institutional affiliations.

\section{Submit your manuscript to a SpringerOpen ${ }^{\circ}$ journal and benefit from:}

- Convenient online submission

- Rigorous peer review

- Open access: articles freely available online

- High visibility within the field

- Retaining the copyright to your article

Submit your next manuscript at $\boldsymbol{\nabla}$ springeropen.com 